\title{
Implications of water extraction on the low-flow hydrology and ecology of tropical savannah rivers: an appraisal for northern Australia
}

\author{
Alison J. King ${ }^{1,2,5}$, Simon A. Townsend ${ }^{1,3,6}$, Michael M. Douglas ${ }^{1,2,7}$, and Mark J. Kennard ${ }^{1,4,8}$ \\ ${ }^{1}$ Tropical Rivers and Coastal Knowledge, National Environmental Research Program Northern Australia Hub, Darwin, Northern \\ Territory 0909 Australia \\ ${ }^{2}$ Research Institute for the Environment and Livelihoods, Charles Darwin University, Darwin, Northern Territory 0909 Australia \\ ${ }^{3}$ Department of Land Resource Management, P.O. Box 496, Palmerston, Northern Territory 0831 Australia \\ ${ }^{4}$ Australian Rivers Institute, Griffith University, Kessels Road, Nathan, Queensland 4111 Australia
}

\begin{abstract}
Balancing the freshwater needs of humans and ecosystems is a fundamental challenge for the management of rivers worldwide. River regulation and water extraction can affect all components of the natural flow regime, yet few studies have investigated the effects on the low-flow end of the hydrograph. Low-flow periods are hydrologically distinctive and ecologically important, varying in nature among climatic zones. Tropical savannah rivers are characterized by highly seasonal and predictable flow regimes, but with high interannual variation in the magnitude, timing, and duration of low flows. Many tropical savannah rivers are relatively intact, especially in northern Australia, but many are now receiving increasing attention for water-resource development through surface- and groundwater extraction. We identified the hydroecological effects of water extraction on 3 phases of the seasonal flow regime: the wet-dry transition, dry season, and dry-wet season transition for perennial and intermittent rivers in tropical savannah climates. We propose a conceptual model and 7 predictions that describe the ecological implications of dry-season water extraction in tropical savannah river systems worldwide. The predictions address: 1) connectivity, 2) availability of in-stream habitat, 3) dry-season persistence of in-channel refugia, 4) water quality during dry-wet and wet-dry transition periods, 5) decoupling of wet- and dry-season flows, and the cumulative effects on 6) groundwater-dependent species and 7) whole-ecosystem shifts. We used northern Australia as a case study to review the current level of evidence in support of these predictions and their potential ecological consequences, and used this review to propose key priorities for future research that are globally applicable.
\end{abstract}

Key words: wet-dry, tropics, water extraction, dry season, savannah landscapes, flow alteration

Fresh waters are the most threatened ecosystem on the planet and exhibit the highest extinction rates of any ecosystem (Dudgeon et al. 2006). Balancing the freshwater needs of humans and ecosystems is a fundamental challenge, with most riverine ecosystems throughout the world highly degraded because of human activity (Nilsson et al. 2005, Vörösmarty et al. 2010, Tedesco et al. 2013). Alteration of natural flow regimes is one of the most significant threats to the ecological health of rivers (Bunn and Arthington 2002, Vörösmarty et al. 2010). Water-resource development can affect all components of the flow regime, but our knowledge of the ecological effects of flow alteration is based largely on studies of changes to medium- and high-flow events (Lake 2000, Poff and Zimmerman 2010). Despite the inherent vulnerability of the low-flow end of the hydrograph to human-induced flow change (Smakhtin 2001), the hydrological and ecological consequences of changes to low flows remain highly uncertain (Lake 2003, Niu and Dudgeon 2011, Walters and Post 2011).

Low-flow periods are distinct and ecologically significant components of the hydrological cycle of all river systems. Rolls et al. (2012) identified 6 ecologically relevant hydrological attributes of low flows (antecedent conditions, duration, magnitude, timing and seasonality, rate of change, and frequency), which vary between climatic regions and river types. They also proposed 4 generalized principles that

E-mail addresses: ${ }^{5}$ alison.king@cdu.edu.au; ${ }^{6}$ simon.townsend@nt.gov.au; ${ }^{7}$ michael.douglas@cdu.edu.au; ${ }^{8}$ m.kennard@griffith.edu.au

DOI: 10.1086/681302. Received 17 May 2014; Accepted 8 January 2015; Published online 20 March 2015.

Freshwater Science. 2015. 34(2):741-758. ๑ 2015 by The Society for Freshwater Science. 
describe the mechanistic links between the low-flow attributes and the ecological responses in riverine ecosystems. The synthesis by Rolls et al. (2012) included studies from all river types (perennial to ephemeral) and considered all types of low-flow regimes, including: predictable seasonal low flows, such as dry-season flows in tropical savannah regions; summer low-flow periods in temperate or mediterranean systems; and abnormal and extended low-flow periods, such as the recent severe 'Millennium' drought in southeastern Australia (van Dijk et al. 2013). However, most of the emphasis by Rolls et al. (2012) was on temperate rivers, and they cautioned that generalizing ecological responses to low flows to other climatic or biogeographic regions is problematic.

For many tropical-river systems, low flows during the dry season are a distinct and predictable period of reduced discharge (Lewis 2008, Warfe et al. 2011). The rivers in the tropical savannah climate region (Peel et al. 2007), also called the wet-dry tropics (e.g., Warfe et al. 2011), display extreme seasonality and predictability, with most of a river's discharge occurring in only a few months because of monsoonal rainfall in the wet season, and low- or zeroflow periods occurring for several months during the dry season (Petheram et al. 2008, Warfe et al. 2011). In these rivers, seasonal low flows result in contraction, and poten- tially disconnection, of aquatic habitats and changes in the availability and quality of resources for aquatic biota.

Tropical savannah regions are the $2^{\text {nd }}$-most-common global climate type. They cover $11.5 \%$ of the world and occur across large parts of Australia, Africa, South America, India, and southeastern Asia (Peel et al. 2007; Fig. 1). Many tropical savannah river systems, such as in India and southeastern Asia, are already among the most threatened river systems on the planet (Vörösmarty et al. 2010), largely because of the effects of groundwater pumping (AeschbachHertig and Gleeson 2012) and high levels of river regulation (Lehner et al. 2011). In contrast, other savannah regions, such as northern Australia, currently have some of the lowest levels of surface- or groundwater extraction in the world (Lehner et al. 2011, Aeschbach-Hertig and Gleeson 2012) and relatively low threats to riverine biodiversity (Vörösmarty et al. 2010). However, interest is growing in developing the water resources to sustain expanded agriculture in northern Australia (Loughnane 2013, Commonwealth of Australia 2014), and much of this expansion will rely on dry-season water extraction.

Over-exploitation of ground water is a global issue (Aeschbach-Hertig and Gleeson 2012), and understanding how river ecosystems will respond to the alteration of seasonal low flows is increasingly important (Smakhtin 2001,

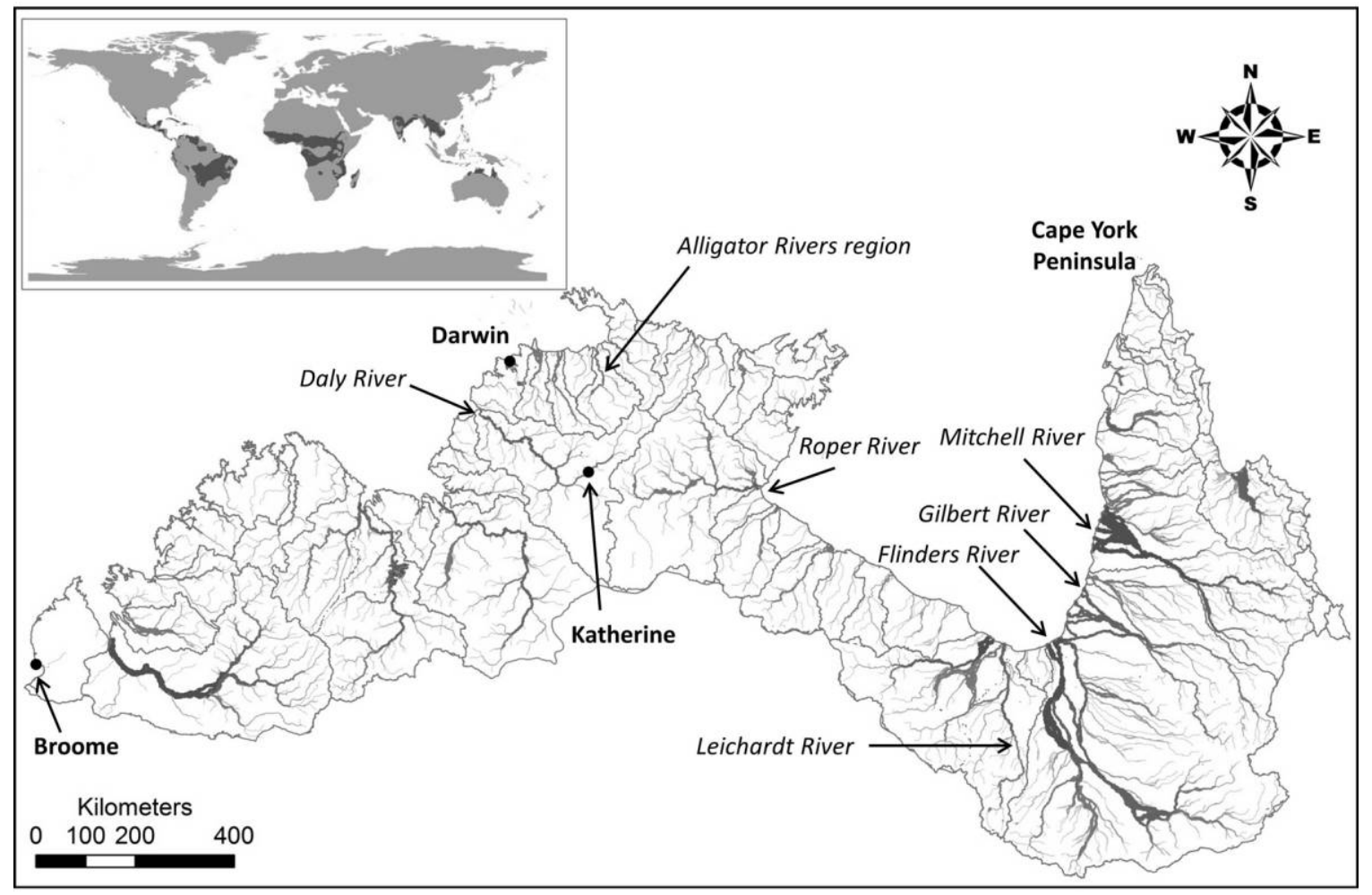

Figure 1. Map of northern Australia showing locations mentioned in the text. Inset map shows the global distribution of the Tropical Savannah Köppen-Geiger climate type Aw highlighted in dark gray (Source: Peel et al. 2007). 
Rolls et al. 2012). The hydrological and ecological effects of water extraction in tropical savannah regions have received little scientific attention, but are likely to be substantial (Benstead et al. 1999, Niu and Dudgeon 2011). For example, Benstead et al. (1999) estimated between 34 and $62 \%$ daily mortality of migrating shrimp larvae that were entrained in surface-water pumps from a tropical river, with mortality increasing to $100 \%$ during low-discharge periods. Niu and Dudgeon (2011) recorded significant declines in macroinvertebrate species richness and compositional metrics in Hong Kong streams with high levels of dryseason water extraction. The ecological effects of droughts and low flows across a range of river types have been explored in many studies (in particular see review by Rolls et al. 2012), and some studies have been made of the effects of direct water extraction on unregulated rivers (see, for example, Castella et al. 1995, McKay and King 2006), but little specific information exists on the likely ecological responses to low-flow alteration in tropical savannah rivers. This key knowledge gap is currently impeding environmental flow management and sustainable water planning in many tropical parts of the world, including in northern Australia (Douglas et al. 2011).

We predicted the hydrological and ecological effects of water extraction on 3 phases of the seasonal flow regime: the wet-dry transition, dry season, and dry-wet season transition periods (sensu Warfe et al. 2011) for perennial and intermittent rivers in tropical savannah climates. We deliberately focused on the effects of surface- or groundwater extraction, and we do not discuss the effects of river regulation, i.e., dam and weir construction and operation, which have received much more attention in the literature (e.g., Dudgeon 2000, Bunn and Arthington 2002, Hart 2004). We reviewed relevant literature on low-flow hydrology and ecology from tropical savannah rivers from northern Australia and elsewhere. We used a conceptual model that describes the mechanistic links to present specific predictions on the hydrological effects of water extraction in tropical savannah rivers worldwide. We critically evaluated the current level and quality of evidence in support of each prediction, assessed their potential ecological consequences, and used this evaluation to identify key priorities for future research. We focused on knowledge derived from rivers of the tropical savannah region of Australia because they are: 1) currently relatively unaffected by humans and, therefore, are useful model systems, and 2) they are under imminent threat from water development. However, we think our predictions are relevant to other tropical savannah rivers throughout the world.

\section{AUSTRALIA'S TROPICAL SAVANNAH RIVERS AND POTENTIAL FUTURE WATER DEVELOPMENT}

Australia's tropical savannah region has one of the largest aggregations of free-flowing rivers in the world (Reidy-
Liermann et al. 2012) and supports highly productive and diverse ecosystems of great social, cultural, and economic value (Pusey et al. 2011). The region extends over $\sim 1.3$ million $\mathrm{km}^{2}$, from Broome in Western Australia, across the northern part of the continent to the tip of Cape York in Queensland (Fig. 1). The region has low population densities and very small areas of intensive land use. The rivers of northern Australia are considered the most biologically diverse and healthy aquatic systems in Australia, and among the least threatened globally by current human activities (Vörösmarty et al. 2010, Pusey et al. 2011). Approximately $30 \%$ of the region's land mass, and many aquatic ecosystems of high conservation value, are owned by indigenous people, with some river catchments entirely within Aboriginalowned land (Jackson et al. 2011). However, Australia's savannah rivers are not pristine. Two-thirds of the total land area of the region supports a low-intensity cattle-grazing industry and other land uses, such as forestry, cropping, horticulture, and mining, which are largely focused around permanent water sources (Woinarski et al. 2007). The region accounts for more than half of Australia's river discharge, but the currently low anthropogenic water demand means that few rivers are impounded, and only 23 water storages have $>1$ GL capacity (Cresswell et al. 2009). Ground water also is largely undeveloped across the region, except for the Daly River, the Darwin-Howard East area near Darwin, and the Western Cape York region (CSIRO 2009a; Fig. 1).

The past decade has seen increasing interest in developing the water resources of the region for agriculture and other human uses (Pusey et al. 2011, Loughnane 2013). Proposals for smaller-scale developments using direct surface- and groundwater extraction are increasing. Large numbers of new dams are unlikely because of the generally low relief, the declining rainfall gradient from the coast inland, variable wet-season rainfall, and high evaporation rates (CSIRO 2009a). However, potential dam sites, off-stream storages, and increased groundwater extraction are being assessed in specific watersheds across the region (e.g., CSIRO 2013, Petheram et al. 2008, 2013).

Governments in the region are actively undertaking water-resource assessment and planning, with the aim of equitable allocation of the available water resource, while conserving the environmental values of the system. For example, in the Daly watershed (Fig. 1), most ground water for the lower Katherine River is reserved for environmental purposes. Seventy percent of ground water discharging into the Katherine River is allocated to the environment during normal-to-wet years and $87 \%$ in very dry (low flow) years (DNREAS 2009). The Mataranka draft Water Allocation Plan for the Roper River (Fig. 1) allocates a maximum annual extraction for consumptive purposes of $15 \%$ of the long-term annual average modeled recharge (20 GL; DLRM 2011). Other groundwater extraction limits have been set as annual volumes (e.g., 10 GL from the Cape York 
region; CSIRO 2009b), but are not explicitly linked to maintenance of stream flow. Direct surface-water extractions during the dry season from intermittent and perennial rivers are currently negligible on a watershed or regional scale, but could be significant at a local scale and could increase in the future (Table 1).

\section{FLOW REGIMES AND HYDROLOGICAL CONSEQUENCES OF WATER EXTRACTION IN TROPICAL SAVANNAH RIVERS}

The tropical savannah region of northern Australia has strongly seasonal monsoonal rainfall, with $>90 \%$ of annual rainfall occurring during the wet season from November to April, and a marked gradient from maxima of $2000 \mathrm{~mm}$ on the coast to $300-400 \mathrm{~mm} 400 \mathrm{~km}$ inland (Warfe et al. 2011). Very little rain falls during the dry season, and river flows recede such that most rivers cease to flow or dry completely before the following wet season, but several iconic perennial rivers in the region rely on significant groundwater input to maintain flows. Despite the relatively high wet-season rainfall, the region is essentially water-limited because of high temperatures and high evaporation rates (Cresswell et al. 2009).

Tropical savannah rivers have a distinct and predictable hydrologic seasonality reflecting the wet-dry climate and can have either permanent or intermittent flows (Kennard et al. 2010, Warfe et al. 2011; Fig. 2A, C). In northern Australia, intermittent flow regimes are the most common hydrological type, but the degree of intermittency varies depending on climate, latitude, and underlying geology, and rivers can cease flowing for up to several months (Kennard et al. 2010; Fig. 2C). Perennial streams and rivers are much less common but do occur in areas with strong surfacewater-groundwater connectivity, such as in the Daly and Roper River basins (Petheram et al. 2008, Kennard et al. 2010; Fig. 2A).

Warfe et al. (2011) recognized 4 hydrological periods for the tropical savannah rivers: 1 ) transition from dry to wet season, 2) wet season, 3) transition from wet to dry season, and 4) dry season (Fig. 2A). Wet-season flow is supplied mainly by surface runoff and shallow subsurface flow from monsoonal rainfall (Fig. 2A), although cyclonic weather and convective storms also contribute. A small proportion of the rainfall, $\sim 10 \%$ annually (Cook et al. 1998), recharges aquifers and raises water tables often by several meters until they fill to capacity and then slowly drain through springs, seepages, and directly into the river, and supply water for the evapotranspiration of deep-rooted trees. Dry-season flows are predominantly groundwater-fed (Fig. 2A) because stormrunoff events are infrequent. The transition from wet to dry season is marked by a gradual shift from surface-dominated flow to groundwater-dominated flow (Fig. 2A). The converse occurs during the dry-to-wet transition (Fig. 2A) when groundwater-fed flow is diluted by episodic storm-runoff events before major wet-season flows. The seasonality of flow in tropical savannah rivers is highly predictable, but the precise timing of these 4 seasons can vary from year to year. Even less predictable is the interannual variation of the magnitude of wet- and dry-season flows (Kennard et al. 2010).

The magnitude of dry-season low flows is linked to the height of groundwater tables and aquifer discharges, which can vary naturally among years in response to wet-season rainfall total and the temporal and spatial distribution of rainfall over the recharge area. Intermittent rivers cease to flow in the dry season because the groundwater supply to the river channel is exhausted (Fig. 2C). In some intermittent systems, the river dries completely, but many decrease to a series of disconnected in-channel pools of highly variable depth (up to $5 \mathrm{~m}$ ), length (up to several kilometers), persistence (weeks to months), and spatial distribution in the systems. The duration of the dry-season low-flow period is determined by the timing of the wet-to-dry transition, and the beginning of the transition to the wet season (Fig. 2C).

Groundwater extraction from bores and wells can significantly reduce river flow by removing water that would have naturally travelled to a river or stream and, therefore, can alter the natural flow regime of perennial and intermittent rivers. This alteration occurs predominantly during the low-flow dry season and shouldering transition periods when water extraction is more likely to occur, and when the river flow is at its lowest and any reduction in flow is more significant (Fig. 2B). The effect of groundwater extraction on stream flow depends on the volume extracted, the travel time between the point of recharge and stream, and the effect of reduced groundwater inflow on stream flow. For example, the number of zero-flow days will increase significantly from historical numbers under theoretical implementation scenarios of the full use of current water allocations (including groundwater and surface water extractions) in many parts of the Leichardt, Flinders, Gilbert, and Mitchell Rivers in Queensland (Close et al. 2012; Fig. 1). The effect of groundwater extraction on river flow may not be apparent for decades because of slow groundwater travel times. This effect is in contrast to the immediate impact of direct surface-water extraction from the river. Groundwater discharging into the Daly River is $\geq 50$ y old (Cook et al. 2003). Dry-season flow reduction caused by groundwater extraction is predicted to occur for the Katherine and Roper Rivers in the next 5 to $50 \mathrm{y}$ and in the Darwin region in the next 5 y (SKM 2012). Groundwater extractions that exceed the annual wet-season recharge will result in a gradual long-term lowering of the water table and a depleted aquifer to supply not only stream flow, but also anthropogenic uses. The incremental decline in flow over decades, overlying natural flow variability, could be considered a ramp disturbance, which is defined by the gradually increasing magnitude of the disturbance temporally and spatially (Lake 2000). 


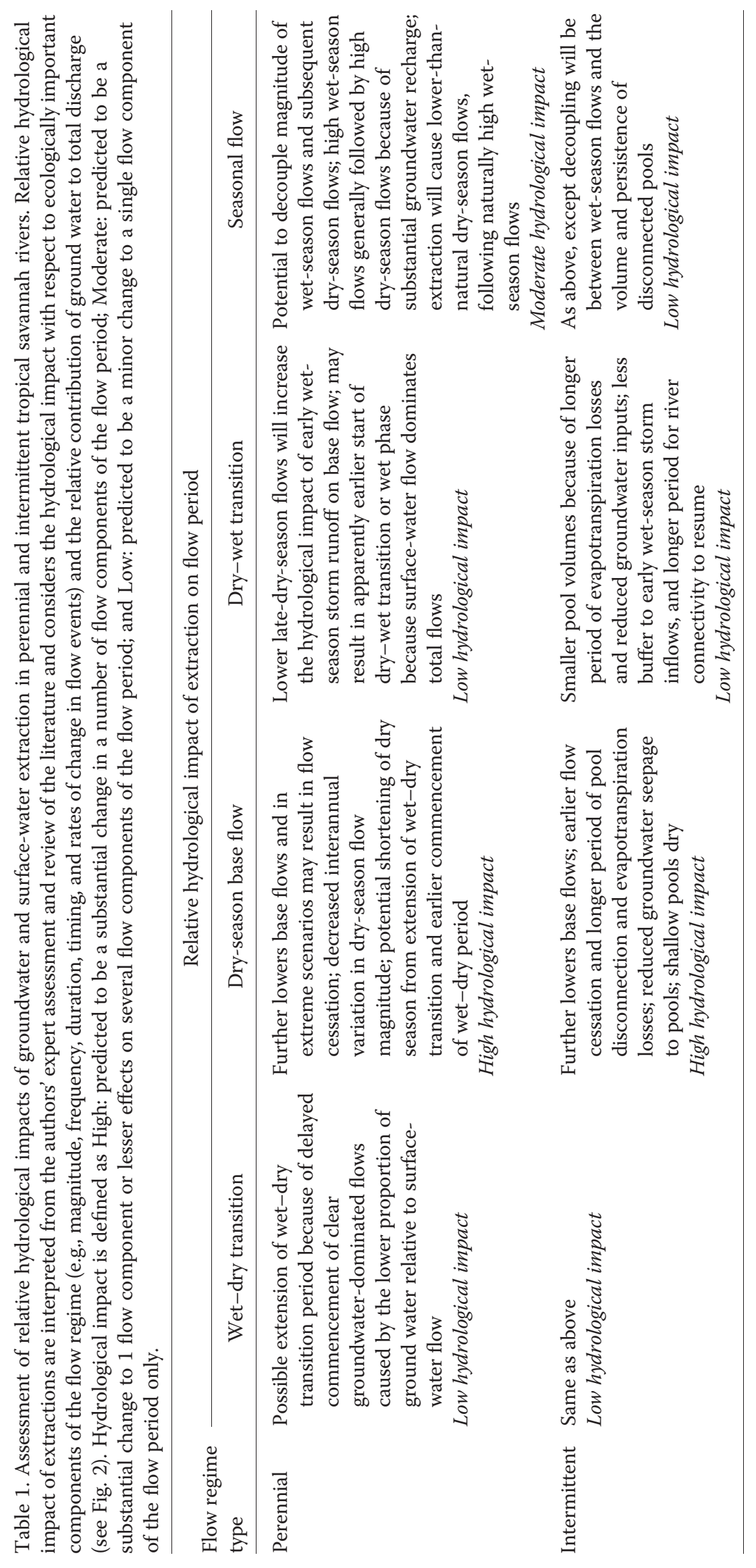




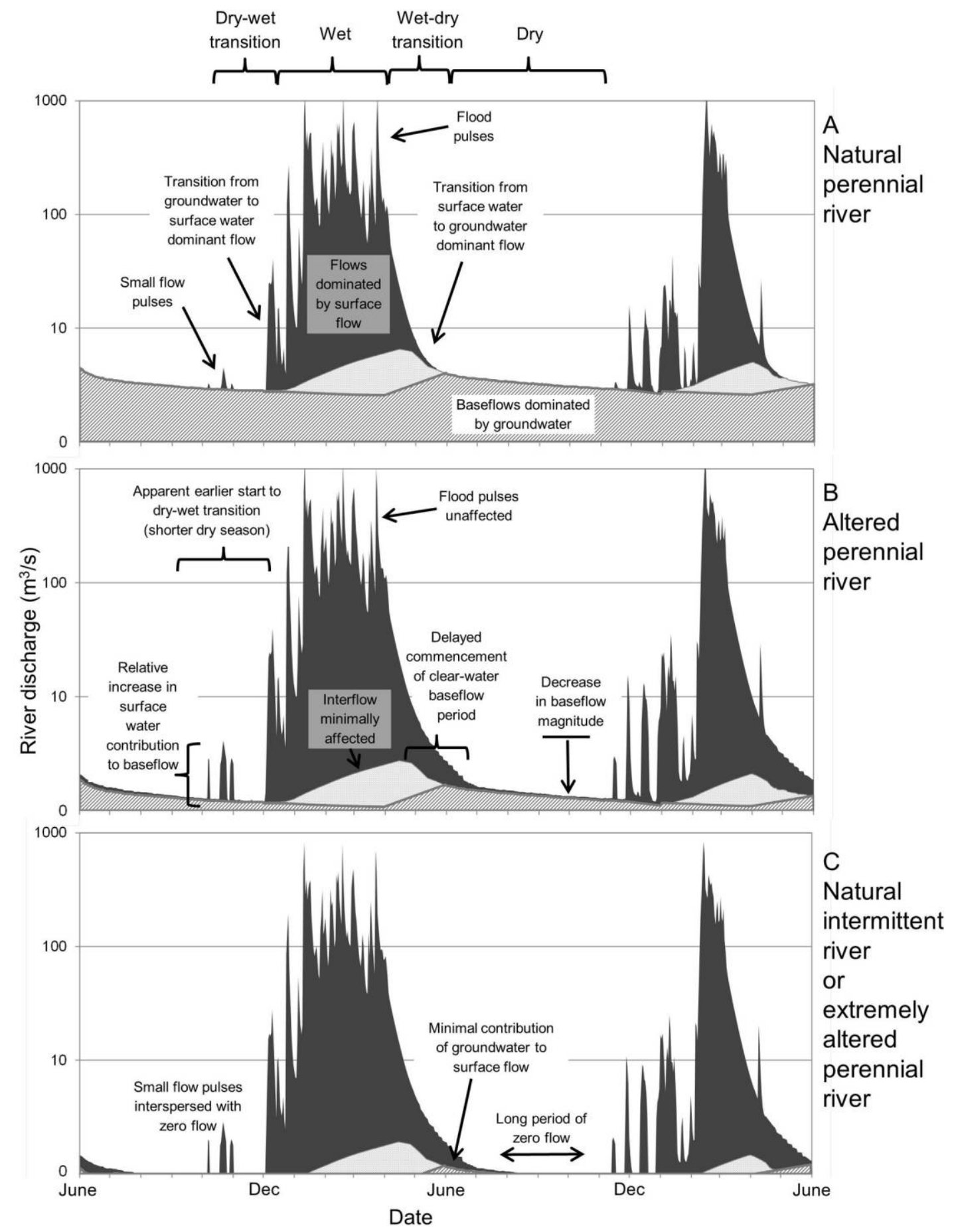

Figure 2. Conceptualization of daily variation in river discharge from surface flows (solid grey fill), interflows (dotted grey fill) and groundwater base flows (diagonal striped fill) for a naturally perennial river (A), a perennial river altered by water extraction (B), and a naturally intermittent river or a perennial river altered by significant water extraction (C). Extraction is assumed to be constant throughout the year and predominantly via ground water. Large surface-water extractions may contribute to other hydrological effects. Surface flow includes all overland flow and precipitation falling directly onto stream channels, interflow is the portion of the stream flow contributed by infiltrated water that moves laterally in the subsurface until it reaches a channel, and groundwater flow is the baseflow component contributed to the channel by ground water (Ramírez 2000). Key hydrologic characteristics and effects of water extraction also are shown. Contributions to river discharge from ground water may be more susceptible to groundwater extraction compared to interflow processes (Costelloe et al. 2014). 
The effect of groundwater and surface-water extraction on the seasonal hydrograph will vary with natural flowregime type, seasonal flow period, the volume extracted, proximity of extraction to the river, and the relative change in ground water as a proportion of total flow. We propose that water extraction will influence the hydrology of tropical savannah perennial and intermittent rivers in 6 ways (Fig. 2A-C, Table 1):

1. A decrease in the magnitude of dry-season base flows in perennial rivers. When groundwater resources are over-exploited and have water tables substantially lower than their natural range, the most significant effect for perennial rivers will be a decrease in dry-season flows, and in extreme circumstance, their cessation.

2. Decoupling of wet- and dry-season flows. A decoupling of wet- and dry-season flows is predicted to occur when wet-season flows remain nearly natural but are followed by dry-season flows with significantly lower flows than the natural flow regime.

3. Altered connection periods in intermittent streams. For intermittent streams, a shortened period of flow connection and an extended period of in-channel pool disconnection and reduced pool levels to buffer early wet-season storm runoff in the wet-dry transition is predicted.

4. An extended dry-wet transition period. A reduced riverine flow magnitude (for perennial rivers) and reduced pool volumes (intermittent rivers) to buffer early wet-season storm runoff in the dry-wet transition will result in the apparently earlier commencement of this transition period.

5. A delayed commencement of dry-season base flow in perennial rivers. The wet-to-dry season transition period is predicted to be extended because of delayed commencement of the clearly groundwaterdominated flow period because of the lower proportion of ground water contributing to total river flow during seasonal recession flow.

6. Prolonged extraction will lead to long-term reductions in groundwater levels. Prolonged groundwater extraction that exceeds aquifer recharge will progressively lower the groundwater table, potentially leading to long-term reductions in groundwater discharge to river flows. This decline can further reduce dry-season riverine base flows and, in extreme scenarios, dry-season flows in perennial rivers could cease.

Our assessment of the relative hydrological impact of dry-season water extraction of flows in perennial and intermittent rivers (Table 1) suggests that, although extraction will affect both dry-season flows and the shouldering transition-flow periods, the effects will be more significant in the low-flow dry-season phase.

\section{PREDICTING THE ECOLOGICAL CONSEQUENCES OF WATER EXTRACTION}

We propose a conceptual model (Fig. 3) and 7 broad, testable predictions to describe the probable ecological consequences of water extraction on tropical savannah rivers. These predictions are based on a critical review of the relevant ecological literature on tropical savannah rivers, particularly from northern Australia and the combined authors' expert knowledge and experience of these river systems. We used literature from other regions where appropriate, and we think these predictions are likely to be applicable to other tropical savannah rivers throughout the world. We focused on northern Australian rivers only to assess the quality of evidence supporting each of the predictions, the likelihood of significant impact, and its ecological consequence (Table 2).

\section{Prediction 1. Water extraction will reduce the connectivity and movement of biota and materials during the dry season}

The dry season is a period of naturally low flows, but water extraction will further reduce discharge and, therefore, the extent of longitudinal, lateral, and vertical connectivity. This reduction, in turn, could limit the transport of nutrients and organic matter and the movement of biota. Low flows reduce the suspension, mobilization, and transport of fine particulate organic matter (Jones and Smock 1991) and benthic organic matter, such as leaves and small woody debris (Dewson et al. 2007), and may reduce the sloughing of benthic algae (Townsend and Padovan 2005, 2009). Longer retention times in river pools and slackwaters will favor the growth and increased biomass of phytoplankton (Townsend et al. 2012). Australia's tropical savannah rivers are generally heterotrophic (Townsend et al. 2011, Hunt et al. 2012) and nutrient limited in the dry season (Webster et al. 2005, Ganf and Rea 2007, Townsend et al. 2008). Hence reductions in groundwater connection during the low-flow period could further restrict nutrient transport from sediments and the hyporheic zone (Rolls et al. 2012). However, the importance of these processes in the dry season relative to in the wet season is unknown (Brodie and Mitchell 2005).

Lower dry-season flows also may limit the longitudinal movement of aquatic biota. Many aquatic organisms, such as macroinvertebrates, early life stages of fish, and plant seeds are obligate drifters and require flow to facilitate dispersal and transport. Reduced discharge may decrease dispersal distance and rates and densities of drifting biota, potentially leading to wider consequences for higher trophic levels, such as limiting growth rates and productivity of predatory consumers (Rolls et al. 2012). Low flows also may 


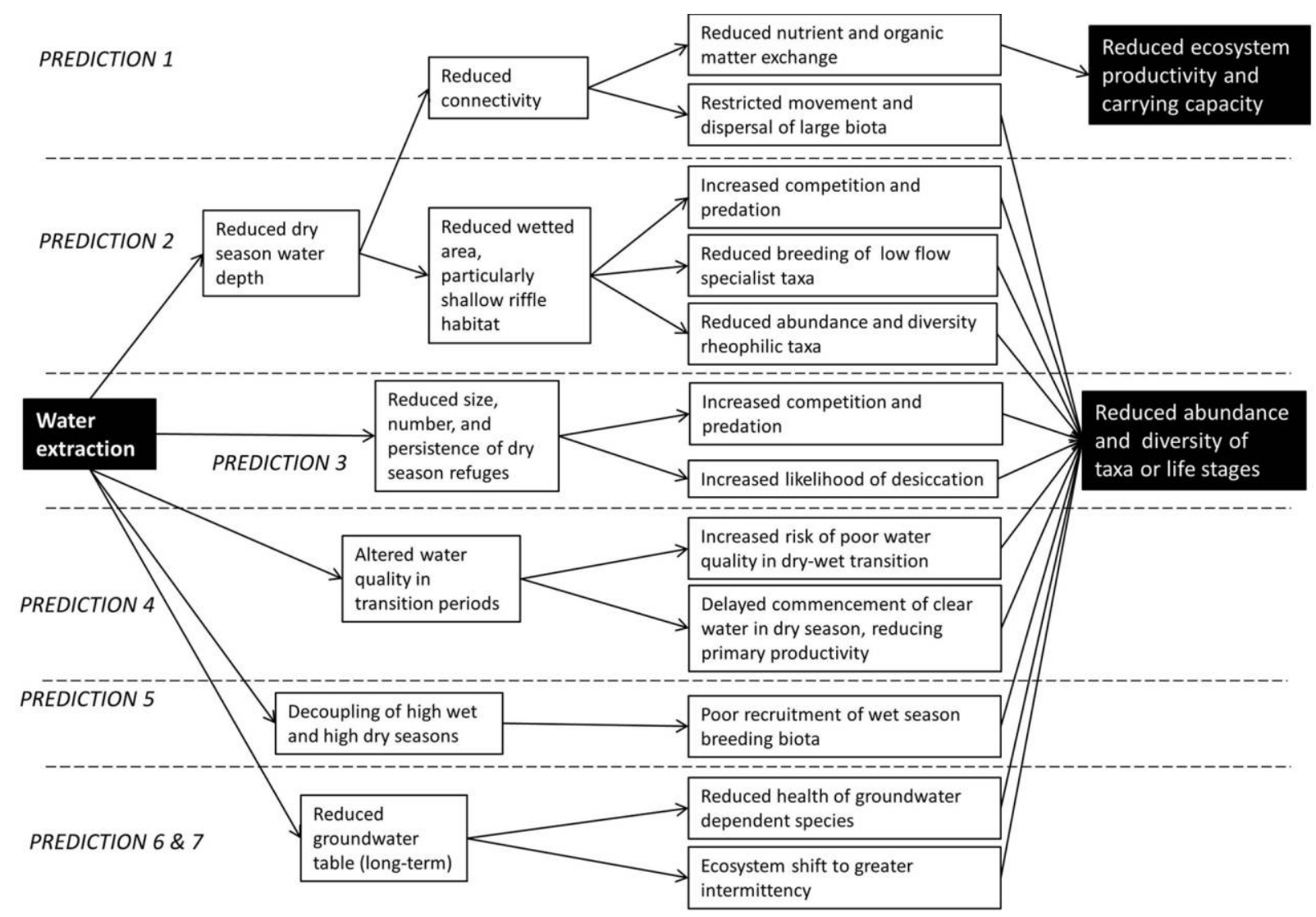

Figure 3. Proposed conceptual model describing mechanistic links between water extraction and potential physical and ecological outcomes in tropical savannah rivers.

trigger the movement of some biota to disperse or seek refuge during drier spells (Magoulick and Kobza 2003). For example, the annual contraction of intermittent and ephemeral rivers in the wet-dry transition period seems to force aquatic macroinvertebrates and fish to disperse, seek suitable dry-season refugia, and then recolonize once wet season flows begin (Bishop et al. 1995, Dostine et al. 1997). The behavioral and ecological responses to dewatering and declining flow conditions and the dispersal requirements of most aquatic biota during the dry season in tropical savannah rivers are poorly known.

Reduced dry-season flows over natural structures, such as rock bars or riffles, or anthropogenic features, such as road crossings and culverts, can create shallower and highervelocity areas that could exceed swimming abilities, and therefore, could restrict the movement of larger biota (e.g., fish, turtles, sharks, and rays). Wet-season flows facilitate annual longitudinal and lateral connection of large fish through the catchment (Jardine et al. 2012b), but the movement requirements of large fish during the dry season in perennial or intermittent rivers are less clear. Anecdotal evidence indicates that recreational fisherman in northern Australia often target moving and aggregating Barramundi
(Lates calcarifer) at culverts, road crossings, or natural rock bars as water levels recede (wet-dry) or rise (dry-wet). Some evidence suggests that juveniles of diadromous fishes (e.g., Freshwater Sole Leptachirus triramus, Ariidae catfish) and shrimp migrate upstream during the receding wet-dry transition period and very early dry season (Benstead et al. 1999, AJK and P. Novak [Charles Darwin University], unpublished data). Therefore, restrictions to free movement could reduce the densities of fauna migrating upstream and create high densities just below the barrier, thereby exposing them to higher levels of predation and competition for resources. Reduced connectivity also can restrict access to food resources for mobile wide-ranging species. For example, the pig-nosed turtle (Carettochelys insculpta) in the Daly River undertakes foraging movements covering $>10 \mathrm{~km}$ of river during the dry season to maintain its body condition and, therefore, is highly susceptible to reductions in dryseason water levels (Georges et al. 2002). Further research in tropical savannah rivers is required on the importance of dry-season movements of biota, particularly whether bottleneck periods occur and whether in-stream barriers to movement are likely to influence metapopulation persistence. 


\section{Prediction 2. Water extraction will reduce the availability of some habitats during the dry season, reducing abundance and diversity of some specialized taxa and life stages}

Lower flows reduce the volume, area, and depth of available aquatic habitat and change the instantaneous velocity of rivers (Rolls et al. 2012). Shallow, fast-flowing habitats (e.g., riffles) are the most vulnerable to reduced discharge in the low-flow period. Reduced densities of rheophilic (prefer to live in fast flows) taxa and life stages, and ultimately, local loss of species can occur with prolonged low flows that extend beyond their normal life span. Examples have been reported throughout the world (e.g., Castella et al. 1995, McKay and King 2006, Miller et al. 2007), but few examples exist that test rheophilic species' resistance and resilience to water extraction in tropical environments (but see Covich et al. 2003).

Riffles are important sites for benthic algae and invertebrate production, which in turn, provide important food resources for fish, birds, and reptiles in tropical savannah rivers (Douglas et al. 2005). The growth and density of benthic algae peaks during the middle of the dry season in the Daly River, then decreases sharply during the late dry season because of autogenic sloughing (Townsend and Padovan 2009). Townsend and Padovan (2009) predicted that reduced dry-season flows would decrease the area of favorable hydraulic conditions for the growth of Spirogyra sp. and, therefore, would limit energy transfer to higher organisms. Similarly, macroinvertebrate diversity is at its highest early in the dry season (with more sensitive and rheophilic taxa occurring), rather than in the late dry season when fewer taxa that are generally resistant to changing water levels and quality occur (Garcia et al. 2011, Leigh 2013). The biota are undoubtedly adapted to natural and seasonal periods of low flows, but flow alteration that increases the likelihood of flow cessation would alter the resistance and resilience of assemblages, such that early wetseason recovery after the dry season may not be reliable (Leigh 2013). Riffles are the preferred habitat for juveniles of many fish species in northern Australian rivers, including Sooty Grunter (Hephaestus fuliginosus) and Butler's Grunter (Syncomistes butleri) (Pusey et al. 2011). Chan et al. (2012) demonstrated that the availability of shallow, fastflowing riffles in the Daly River is very sensitive to variation in dry-season discharge. Hence, reductions in riffle availability caused by dry-season water extraction could have severe consequences for recruitment and population persistence of these riffle-dependent species.

In tropical rivers, breeding of most biota is thought to occur during the resource-rich wet season. For example, most freshwater fish in northern Australia are thought to breed during the wet or shoulder transition phases (Bishop et al. 2001, Pusey et al. 2004). A reduction in low-flow discharge could reduce the availability of breeding and rear- ing habitats for species that preferentially breed during the dry season. Known dry-season breeders include freshwater crocodiles (Crocodylus johnstoni) (Compton 1981) and pig-nosed turtles (Doody et al. 2001). The low-flow period is an important spawning and recruitment period for some fish species in temperate floodplain rivers (see Humphries et al. 1999, King 2004), and recent evidence suggests that dry-season spawning and recruitment does occur for some species in Australian tropical rivers (Pusey et al. 2002, 2004, Doidge 2014). Further research is required in tropical savannah rivers to understand the breeding and nursery habitat requirements of dry-season breeding biota, their susceptibility to low-flow alteration, and the resulting consequences for recruitment.

\section{Prediction 3. Water extraction will reduce the size, number, persistence, and quality of in-channel refugia available during the dry season, particularly in intermittent systems}

Intermittent rivers are the most common river type in northern Australia (Kennard et al. 2010). These rivers often contract to a series of isolated within-channel or floodplain waterholes during the dry season. The waterholes, or refugia, are critical for the survival of aquatic biota during the dry season and are important sources of recolonizing biota during the dry-wet transition phase, when isolated refugia reconnect and biota can move to more favorable environments (Dostine et al. 1997, Pettit et al. 2012). As the dry season progresses, smaller disconnected waterholes are often harsh environments, where habitat area and water quality decline markedly and the limiting effects of competition and predation play an increasing role (Pettit et al. 2012). Deeper waterholes or refugia with constant groundwater connections typically retain habitat and water quality, sustaining high biodiversity throughout the dry season (Townsend 2006). Dostine et al. (1997) proposed that the significance of dry-season refugia for macroinvertebrate recolonization of temporary streams in the wet season is governed by 3 factors: the nature of the substrate (with sandy substrates acting as a significant refuge for resting stages of microcrustacea), the severity of the dry season (described by its duration and the number of refugia remaining), and the proximity of permanent refugia to the temporary stream. The location of refugia within the landscape also is critical for biotic recovery when high flows return (Beesley and Prince 2010).

As the dry season progresses, the ecological stability of isolated, smaller refugia declines. As resources become more limited, the breadth of fish diets may narrow and become poorer in quality (Balcombe et al. 2005, Winemiller et al. 2008) as they become more dependent on localized food sources (Jardine et al. 2013). In Neotropical rivers, the potential for competition and predation in refugia can increase as the dry season progresses (Winemiller 1996, Rodríguez 


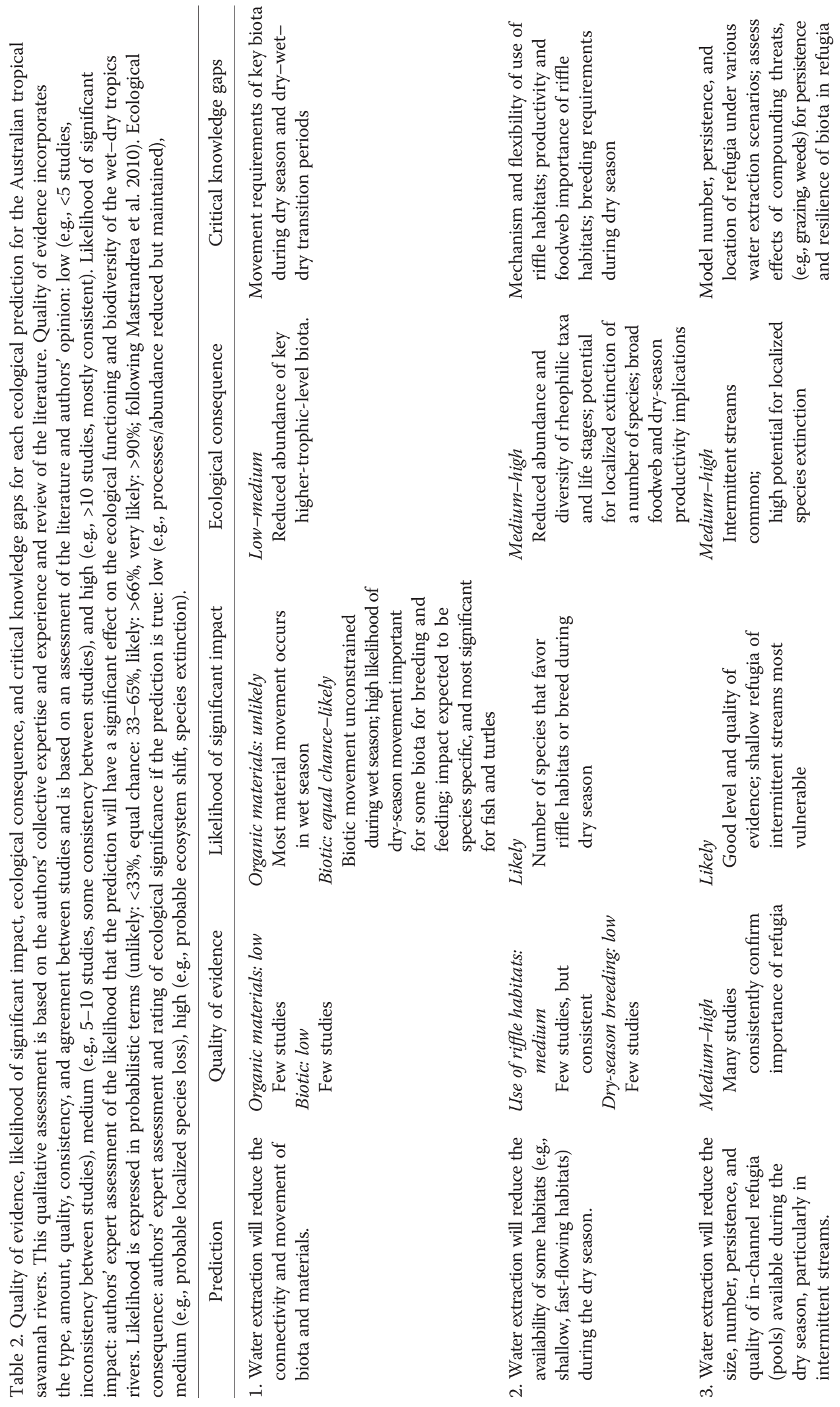



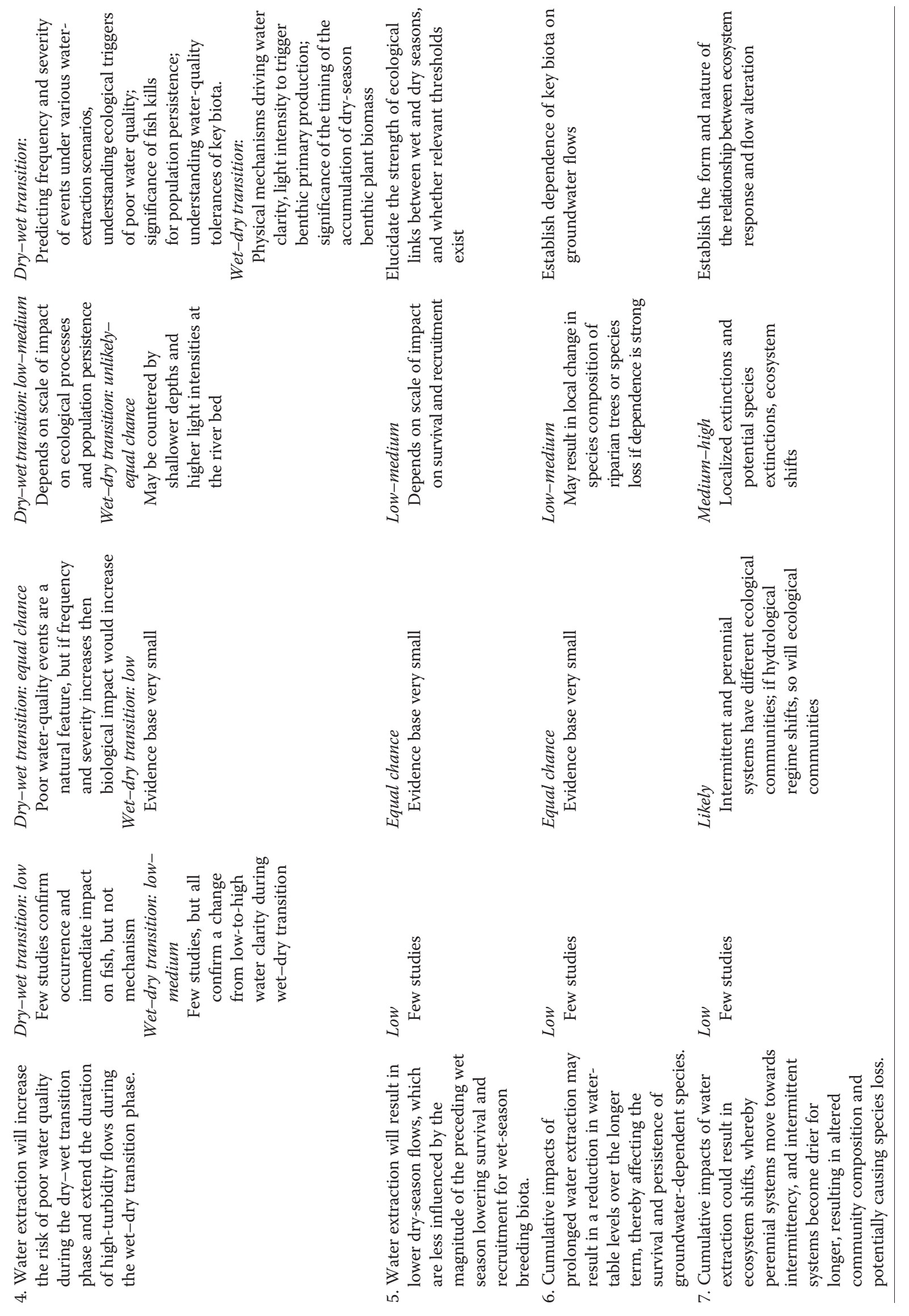
and Lewis 1997). Water quality, such as dissolved $\mathrm{O}_{2}$ concentration, also can deteriorate (Pettit et al. 2012) and increase the likelihood of fish kills (Townsend 1994). Water extraction is likely to exacerbate these effects and may threaten population persistence of susceptible taxa (most likely those with limited dispersal capabilities) if suitable refugia become unavailable or are patchily distributed. For example, McJannet et al. (2014) suggested that under some drier climate-change predictions, reductions of $>60 \%$ of instream refugia would be expected in the Flinders and Gilbert catchments, Queensland. Modeling the proportion and spatial location of refugia likely to be lost under future waterextraction scenarios and predicting which biota will be most heavily affected by stranding and desiccation is a research priority for northern Australia.

\section{Prediction 4. Water extraction will increase the risk of poor water quality during the dry-wet transition phase and extend the duration of high-turbidity flows during the wet-dry transition phase}

The dry-wet transition period is marked by numerous isolated storm events that generate pulses of surface runoff that fill and reconnect refugia and small dry or intermittent tributary streams (Fig. 2A). These first flush events are likely to have poor water quality because they inundate previously dry ground, carry a pulse of organic matter, sediment, nutrients, and (potentially) heavy metal concentrations, and often have very low dissolved $\mathrm{O}_{2}$ concentrations (Townsend 1994, Warfe et al. 2011, Townsend et al. 2012). The poor water quality in some of these events results in severe fish kills, with large numbers and many species affected (Townsend et al. 1992, Townsend 1994, Townsend and Edwards 2003). These events do occur naturally in tropical savannah rivers, but water extraction could lead to more frequent, severe, and prolonged hypoxia or poor-waterquality events as the 'buffering' capacity of the main channel and refugial waterholes is reduced as a result of lower volumes to dilute poor-quality inflows. However, little is known about the capacity for tropical savannah rivers to recover from such events, particularly after the next wetseason high flows, and whether resilience can be sustained if the frequency of hypoxic events increases.

Changes in water chemistry also can cause major shifts in dry-season invertebrate community composition in perennial rivers. For example, sandstone aquifers in the upper reaches of the Katherine River, Northern Territory, provide low-alkalinity groundwater inputs to the river, whereas further downstream, a calcareous aquifer provides highalkalinity ground water to the river. This chemical change corresponds to major differences in invertebrate community composition (Garcia et al. 2011). Changes in the source and mix of groundwater inputs leading to altered water chemistry are a potential consequence of groundwater extraction and, therefore, can alter macroinvertebrate assemblages.
Tropical savannah rivers are highly turbid during the wet season, but the water clears as flow becomes progressively dominated by ground water (Townsend and Padovan 2005, Webster et al. 2005), which has intrinsically low turbidity, though sometimes can be highly colored (Lewis 2008). The increased water clarity in the Daly River permits commencement of benthic primary production, initially dominated by microalgae and Spirogyra and later by Ribbonweed (Vallisneria nana) (Webster et al. 2005). This primary production provides a base for dry-season food webs (Jardine et al. 2012a) and habitat for aquatic biota. A delay in the commencement of clear, dry-season flows is predicted to delay commencement of benthic primary production with possibly wider ecological implications.

\section{Prediction 5. Water extraction will result in lower dry-season flows, which are less influenced by the magnitude of the preceding wet season, thereby decreasing survival and recruitment for wet-season breeding biota}

In years with higher-than-average rainfall during the wet season, higher river discharge and groundwater-recharge rates occur and result in higher flows during the subsequent dry season (Knapton 2009). Many northern Australian freshwater fish reproduce during the wet season (Bishop et al. 2001, Pusey et al. 2004). Large wet-season flows are likely to result in high recruitment pulses as a result of both high levels of spawning in the large wet-season flows, and higher juvenile survival as a result of the subsequent higher dryseason flows. For example, the recruitment strength of Barramundi and Sooty Grunter in the dry season is highly correlated to the preceding wet-season discharge (StauntonSmith et al. 2004, Halliday et al. 2008, Stewart-Koster et al. 2011). However, significant water extraction could reduce dry-season discharge so that it is no longer correlated with the magnitude of the preceding wet season. This decoupling may result in competition among large numbers of juveniles for limited resources in the following dry season with lower flow conditions than expected. Very little is known about the mechanism of impact (e.g., increased predation, limited food resources), but future research could aim to elucidate the strength of ecological links between wet and dry seasons via examination of long-term, quantitative-catch data sets. Over the longer term, decoupling of wet- and dry-season flows would alter assemblage composition, favoring species more adapted to high inter- and intra-annual variability.

\section{Prediction 6. Cumulative effects of prolonged water extraction may result in a reduction in water-table levels over the longer term, affecting the survival and persistence of groundwater-dependent species}

Sustained water extraction could progressively and significantly lower groundwater levels (Sophocleous 2002). Predicting the longer-term ecological effect of systemic and de- 
clining groundwater levels is difficult. Close et al. (2012) suggested that, even allowing for the possibility of increased recharge under future climate scenarios, groundwater levels are likely to continue to decline in areas with significant groundwater extraction, such as the Darwin rural area. This groundwater decline is predicted to threaten a number of groundwater-dependent ecosystems in the area. Groundwater extraction may disturb subterranean and groundwater ecosystems, which may contain unique stygofauna (Hancock et al. 2005, Humphreys 2008). In addition, surface-dwelling groundwater-dependent species are at risk. For example, ground water is a significant source of water for many riparian tree species in the Daly River system during the dry season, potentially accounting for $>50 \%$ of the water transpired during this time (Lamontagne et al. 2005, O'Grady et al. 2006). If the groundwater table falls below the root zone of some riparian tree species, then it is likely that the species composition of the riparian zone will change.

\section{Prediction 7. Cumulative impacts of water extraction could result in ecosystem shifts, in which perennial systems move toward intermittency, and intermittent systems become drier for longer, resulting in altered community composition and potentially causing species loss}

Long-term over-exploitation of available water resources will result in progressively lower water-table levels, which could disconnect normally connected reaches, shift the flow regime from perennial to intermittent (Pusey and Kennard 2009), and cause major ecological change. For example, macroinvertebrate and fish communities differ distinctly between lotic and lentic tropical savannah river systems (Leigh and Sheldon 2009, Pusey et al. 2011). An unnatural shift from one predominant flow state to the other could potentially cause the ecological community to change to suit the new conditions and could result in localized extinctions. A long-term study in the Alligator Rivers region, Northern Territory, suggested that macroinvertebrate communities changed from lotic- to lentic-dominated taxa over an 11-y period of below-average rainfall, and consequently lower dryseason flows (Dostine and Humphrey 2012). This change led to a change from high abundances of rheophilic taxa to near extinction of these taxa. Moreover, the change persisted well after the years of low flows and did not recover during wetter years. In particular, initially dominant taxa, including Leptophlebiidae and Baetidae, hydropsychid caddisflies, and hydrophilid beetles, declined in abundance, whereas Caenidae and Pyralidae increased in abundance.

Significant alterations to the flow regime also can cause shifts in life-history traits. For example, taxa in ephemeral systems tend to have higher proportions of taxa with short life spans, small body size, low fecundity, and multiple batch recruitment (Bonada et al. 2007, Chakona et al. 2008, Arscott et al. 2010). For example, Chakona et al. (2008) dem- onstrated that smaller-bodied macroinvertebrates and species with multiple batch recruitment were more abundant in ephemeral than intermittent streams in Zimbabwe. Similarly, catch rates of shrimp in a perennial rainforest stream in Puerto Rico declined during a severe drought and then recovered quickly, but the reproductive activity of 1 species remained low and did not recover for $\geq 3$ y post drought (Covich et al. 2003).

\section{SYNTHESIS AND IMPLICATIONS}

Predicting the ecological responses to human-induced environmental change is a paramount challenge in science. Relatively intact rivers and their biota in northern Australia (Douglas et al. 2011) and other tropical regions throughout the world (Vörösmarty et al. 2010) are under increasing threat from anthropogenic changes associated with water-resource development. A major challenge for researchers and managers is to anticipate how these threats will influence ecosystem processes and biota so that appropriate strategies can be developed to respond to the threats. The Northern Australia Land and Water Taskforce (2009) highlighted the need for a greater understanding of surfacewater-groundwater interactions so that the effects of water extraction on river ecology could be assessed. Similarly, an urgent call has been made for research and information on quantitative flow-ecology relationships to underpin waterallocation planning and future monitoring in northern Australian rivers (Douglas et al. 2011, Warfe et al. 2011).

Our conceptual model and predictions draw together the best information currently available on the potential hydrological and ecological effects of dry-season water extraction in tropical savannah rivers. These predictions will allow researchers and managers to consider the range of potential effects of dry-season water extraction, with a view to informing policy debates and helping to focus future research activities. We used northern Australian rivers as our primary reference point, but we think our predictions are very likely to be applicable in other regions. They are intended to spur discussion about rivers in tropical savannah regions throughout the world. Our predictions are testable, and we encourage further research that may support, refute, or review them.

Many of the predictions currently have low-to-medium quality of evidence supporting them, mostly because relatively few publications on these topics exist for savannah streams (Table 2). However, the high level of consistency among these findings means that the likelihood that water extraction could create a significant impact is generally medium to high. We also think that the scale of the ecological consequences is generally medium to high. Our analysis highlights a number of critical knowledge gaps (Table 2) that should be addressed to increase confidence in effective water planning and environmental-flow decision-making. A range of approaches would be appropriate to fill these 
knowledge gaps. These approaches include field-based sampling along spatial and temporal hydrological gradients, monitoring of ecological responses to experimental flow manipulations (Konrad et al. 2011, Olden et al. 2014), and modelling approaches such as Bayesian Belief Network modeling that has the capacity to combine different types of knowledge and data (e.g., Chan et al. 2012). However, each of these approaches has inherent strengths, weaknesses, and feasibility constraints in tropical savannah rivers. Constraints include issues of transferability of knowledge and data from one place to another, the feasibility and logistical constraints in undertaking field studies in remote areas that are highly seasonal, costs of undertaking research programs, and the constraints on human resources and scientific knowledge to undertake them.

We acknowledge that our review has focused only on the direct effects of water extraction on hydrology and ecology, and has largely ignored other concurrent effects that are likely to occur with increasing water development. For example, increasing agricultural and mining development may introduce multiple stressors on the aquatic environment. These stressors include changing landscape-scale patterns of land use, which would increase catchment erosion rates and, therefore, potential sediment input to waterways, thereby increasing concentrations of nutrients, pesticides, and other toxicants (Brodie and Mitchell 2005). Changes in land use also would increase road infrastructure and, therefore, the number of potential in-stream barriers (Douglas et al. 2011). Fresh waters are known to be at great risk of multiple-stressor effects (Ormerod et al. 2010), so it will be important to understand the relative effect of each of these potential stressors. The compounding influence of climate change on water-resource development also should be considered. Climate-change predictions are imprecise for northern Australia, but the likelihood of higher temperatures, evapotranspiration rates, and extreme storm events will increase (Morrongiello et al. 2011). These changes would result in greater flow variability in rivers, with decreases in flow or flow cessation occurring more frequently and peak flows during the wet season occurring more sporadically. Hence, our water-extraction predictions are likely to be further exacerbated under many potential climate-change scenarios. This likelihood highlights the critical need for ecologically sound water-resource planning and decision-making in northern Australia that incorporates all potential waterdevelopment effects and other significant confounding impacts.

\section{ACKNOWLEDGEMENTS}

We acknowledge the Australian Government Department of Sustainability, Environment, Water, Population and Communities, the National Water Commission, the Tropical Rivers and Coastal Knowledge (TRaCK) Research Hub, and the National Environmental Research Program. We also thank Peter Dostine, Brad Pu- sey, Erica Garcia, David Crook, Peter Novak, Tom Rayner, and Vanessa Adams for contributing to early thoughts and discussions.

\section{LITERATURE CITED}

Aeschbach-Hertig, W., and T. Gleeson. 2012. Regional strategies for the accelerating global problem of groundwater depletion. Nature Geoscience 5:853-861.

Arscott, D. B., S. Larned, M. R. Scarsbrook, and P. Lambert. 2010. Aquatic invertebrate community structure along an intermittence gradient: Selwyn River, New Zealand. Journal of the North American Benthological Society 29:530-545.

Balcombe, S., S. E. Bunn, F. J. McKenzie-Smith, and P. M. Davies. 2005. Variability of fish diets between dry and flood periods in an arid zone floodplain river. Iournal of Fish Biology 67:1552-1567.

Beesley, L. S., and J. Prince. 2010. Fish community structure in an intermittent river: the importance of environmental stability, landscape factors and within-pool habitat descriptors. Marine and Freshwater Research 61:605-614.

Benstead, J. P., J. G. March, C. M. Pringle, and F. N. Scatena. 1999. Effects of a low-head dam and water abstraction on migratory tropical stream biota. Ecological Applications 9: 656-668.

Bishop, K. A., S. A. Allen, D. A. Pollard, and M. G. Cook. 2001. Ecological studies on the freshwater fishes of the Alligator Rivers region, Northern Territory. Report 145. Supervising Scientist for the Alligator Rivers Region, Australian Government Publishing Service, Canberra. (Available from: www .environment.gov.au/ssd)

Bishop, K. A., R. W. J. Pidgeon, and D. J. Walden. 1995. Studies on fish movement dynamics in a tropical floodplain river: prerequisites for a procedure to monitor the impacts of mining. Australian Journal of Ecology 20:81-107.

Bonada, N., M. Rieradevall, and N. Prat. 2007. Macroinvertebrate community structure and biological traits related to flow permanence in a Mediterranean river network. $\underline{\text { Hydro- }}$ biologia 589:91-106.

Brodie, J., and A. Mitchell. 2005. Nutrients in Australian tropical rivers: changes with agricultural development and implications for receiving environments. Marine and Freshwater Research 56:279-302.

Bunn, S. E., and A. H. Arthington. 2002. Basic principles and ecological consequences of altered flow regimes for aquatic biodiversity. Environmental Management 30:492-507.

Castella, E., M. Bickerton, P. D. Armitage, and G. E. Petts. 1995. The effects of water abstractions on invertebrate communities in U.K. streams. Hydrobiologia 308:167-182.

Chakona, A., C. Phiri, C. Magadza, and L. Brendonck. 2008. The influence of habitat structure and flow permanence on macroinvertebrate assemblages in temporary rivers in northwestern Zimbabwe. Hvdrobiologia 607:199-209.

Chan, T. U., B. T. Hart, M. J. Kennard, B. J. Pusey, W. Shenton, M. M. Douglas, E. Valentine, and S. Patel. 2012. Bayesian network models for environmental flow decision making in the Daly River, Northern Territory, Australia. River Research and Applications 28:283-301.

Close, P. G., J. Wallace, P. Bayliss, R. Bartolo, D. Burrows, B. J. Pusey, C. J. Robinson, D. McJannet, F. Karim, G. Byrne, S. 
Marvanek, C. Turnadge, G. Harrington, C. Petheram, L. X. C. Dutra, R. Dobbs, N. Pettit, A. Jankowski, T. Wallington, F. Kroon, D. Schmidt, B. Buttler, M. Stock, A. Veld, P. Speldewinde, B. A. Cook, B. Cook, M. Douglas, S. Setterfield, M. Kennard, P. Davies, J. Hughes, R. Cossart, N. Conolly, and S. Townsend. 2012. Assessment of the likely impacts of development and climate change on aquatic ecological assets in Northern Australia - Final Report. A report for the Australian Government Department of Sustainability, Environment, Water, Population and Communities (DSEWPaC) and the National Water Commission (NWC). Tropical Rivers and Coastal Knowledge (TRaCK) Commonwealth Environmental Research Facility, Charles Darwin University, Darwin, Australia. (Available from: http://www.environment.gov.au/resource /assessment-likely-impacts-development-and-climate-change -aquatic-ecological-assets-northern)

Commonwealth of Australia. 2014. Green paper on developing northern Australia. Australian Government, Canberra. (Available from https://northernaustralia.dpmc.gov.au/green-paper)

Compton, A. W. 1981. Courtship and nesting behaviour of the freshwater crocodile, Crocodylus johnstoni, under controlled conditions. Australian Wildlife Research 8:443-450.

Cook, P. G., G. Favreau, J. C. Dighton, and S. Tickell. 2003. Determining natural groundwater influx to a tropical river using radon, chlorofluorocarbons and ionic environmental tracers. Iournal of Hydrology 277:74-88.

Cook, P. G., T. J. Hatton, D. Pidsley, A. L. Herczeg, A. Held, A. O'Grady, and D. Eamus. 1998. Water balance of a tropical woodland ecosystem, Northern Australia: a combination of micro-meteorological, soil physical and groundwater chemical approaches. Journal of Hydrology 210:161-177.

Costelloe, J. F., T. J. Peterson, K. Halbert, A. W. Western, and J. J. McDonnell. 2014. Groundwater surface mapping informs sources of catchment baseflow. Hydrology and Earth System Sciences 11:12405-12441.

Covich, A. P., T. A. Crowl, and F. N. Scatena. 2003. Effects of extreme low flows on freshwater shrimps in a perennial tropical stream. Freshwater Biology 48:1199-1206.

Cresswell, R., C. Petheram, G. Harrington, H. Buettikofer, M. Hodgen, P. Davies, and L. Li. 2009. Water resources in northern Australia. Pages 1.1-40 in P. Stone (editor). Northern Australia Land and Water Science Review. Final report to the Northern Australia Land and Water Taskforce. CSIRO Publishing, Canberra, Australia. (Available from http://www .regional.gov.au/regional/ona/nalwt.aspx)

CSIRO (Commonwealth Scientific and Industrial Research Organisation). 2009a. Water in northern Australia. Summary of reports to the Australian Government from the CSIRO Northern Australia Sustainable Yields Project. CSIRO, Canberra Australia. (Available from: http://www.csiro.au/Portals/Publications /Research-Reports/NASY-Summary-report.aspx)

CSIRO (Commonwealth Scientific and Industrial Research Organisation). 2009b. Water in the Gulf of Carpentaria drainage division. A report to the Australian Government from the CSIRO Northern Australia Sustainable Yields Project. CSIRO Water for a Healthy Country Flagship, Canberra, Australia. (Available from: http://www.csiro.au/Organisation-Structure /Flagships/Water-for-a-Healthy-Country-Flagship/Sustainable -Yields-Projects/NASY-Gulf-of-Carpentaria.aspx)
CSIRO (Commonwealth Scientific and Industrial Research Organisation). 2013. Agricultural resource assessment for the Gilbert catchment. An overview report to the Australian Government from the CSIRO Flinders and Gilbert Agricultural Resource Assessment, part of the North Queensland Irrigated Agriculture Strategy. CSIRO Water for a Healthy Country and Sustainable Agriculture Flagships, Canberra, Australia. (Available from: http://www.csiro.au/Organisation-Structure /Flagships/Water-for-a-Healthy-Country-Flagship/Sustainable -Yields-Projects/Flinders-and-Gilbert-Agricultural-Resource -Assessment-overview.aspx)

Dewson, Z. S., A. B. W. James, and R. G. Death. 2007. Invertebrate community responses to experimentally reduced discharge in small streams of different water quality. Journal of the North American Benthological Societv 26:754-766.

DLRM (Department of Land Resource Management). 2011. Draft water allocation plan Tindall Limestone Aquifer, Mataranka, November 2011. Department of Land Resource Management, Northern Territory Government, Darwin, Australia. (Available from: http://www.lrm.nt.gov.au/water/water_allocation/plans /mtlawap)

DNREAS (Department of Natural Resources, Environment, the Arts and Sport). 2009. Water allocation plan for the Tindall Limestone Aquifer, Katherine 2009-2019. Department of Natural Resources, Environment, the Arts and Sport, Northern Territory Government, Katherine, Australia. (Available from: http://www.territorystories.nt.gov.au/handle/10070/228126)

Doidge, C. 2014. Fish spawning and recruitment in a large floodplain river in the wet-dry tropics of northern Australia: are low flows important? Honours thesis. Charles Darwin University, Darwin, Australia.

Doody, J. S., A. Georges, J. E. Young, M. D. Pauza, A. L. Pepper, R. L. Alderman, and M. A. Welsh. 2001. Embryonic aestivation and emergence behaviour in the pig-nosed turtle, $\mathrm{Ca}$ rettochelys insculpta. Canadian Journal of Zoology 79:10621072.

Dostine, P. L., and C. L. Humphrey. 2012. Macroinvertebrate responses to reduced baseflow in a stream in the monsoonal tropics of northern Australia. National Water Commission, Canberra, Australia. (Available from: http://archive.nwc.gov .au/_data/assets/pdf_file/0020/23078/monsoonal-tropics-of -NT.pdf)

Dostine, P. L., C. L. Humphrey, R. M. Paltridge, and A. J. Boulton. 1997. Macroinvertebrate recolonization after re-wetting of a tropical seasonally-flowing stream (Magela Creek, Northern Territory, Australia). Marine and Freshwater Research 48:633-645.

Douglas, M., S. Jackson, S. Setterfield, B. Pusey, P. Davies, M. Kennard, D. Burrows, and S. Bunn. 2011. Northern futures: threats and opportunities for freshwater ecosystems. Pages 203220 in B. J. Pusey (editor). Aquatic biodiversity in Northern Australia: patterns, threats and future. Charles Darwin University Press, Darwin, Australia.

Douglas, M. M., S. E. Bunn, and P. M. Davies. 2005. River and wetland food webs in Australia's wet-dry tropics: general principles and implications for management. Marine and Freshwater Research 56:329-342.

Dudgeon, D. 2000. Large-scale hydrological changes in tropical Asia: prospects for riverine biodiversity. BioScience 50:793806. 
Dudgeon, D., A. H. Arthington, M. O. Gessner, Z. I. Kawabata, D. J. Knowler, C. Lévêque, R. J. Naiman, A. H. Prieur-Richard, D. Soto, M. L. J. Stiassny, and C. A. Sullivan. 2006. Freshwater biodiversity: importance, threats, status and conservation challenges. Biological Reviews 81:163-182.

Ganf, G. G., and N. Rea. 2007. Potential for algal blooms in tropical rivers of the Northern territory, Australia. Marine and Freshwater Research 58:315-326.

Garcia, E. A., P. Dostine, C. Humphrey, M. M. Douglas, B. J. Pusey, and B. Cook. 2011. Aquatic invertebrates. Pages 5170 in B. J. Pusey (editor). Aquatic biodiversity in Northern Australia: patterns, threats and future. Charles Darwin University Press, Darwin, Australia.

Georges, A., I. T. Webster, E. Guarino, M. C. Thoms, P. Jolly, and S. Doody. 2002. Modelling dry season flows and predicting the effects of water extraction on a flagship species [Project ID: 23045]. CRC for Freshwater Ecology and the Applied Ecology Research Group, University of Canberra, Canberra. (Available from: http://www.environment.gov.au/resource/modelling -dry-season-flows-and-predicting-impact-water-extraction -flagship-species)

Halliday, I. A., J. B. Robins, D. G. Mayer, J. Staunton-Smith, and M. J. Sellin. 2008. Effects of freshwater flow on the year-class strength of a non-diadromous estuarine finfish, king threadfin (Polydactylus macrochir), in a dry-tropical estuary. Marine and Freshwater Research 59:157-164.

Hancock, P., A. J. Boulton, and W. F. Humphreys. 2005. Aquifers and hyporheic zones: towards an ecological understanding of groundwater. Hydrogeology Journal 13:98-111.

Hart, B. T. 2004. Environmental risks associated with new irrigation schemes in Northern Australia. Ecological Management and Restoration 5:106-110.

Humphreys, W. F. 2008. Rising from down under: developments in subterranean biodiversity in Australia from a groundwater fauna perspective. Invertebrate Systematics 22:85-101.

Humphries, P., A. J. King, and J. D. Koehn. 1999. Fish, flows and flood plains: links between freshwater fishes and their environment in the Murray-Darling River system, Australia. Environmental Biology of Fishes 56:129-151.

Hunt, R. J., T. D. Jardine, S. K. Hamilton, and S. E. Bunn. 2012. Temporal and spatial variation in ecosystem metabolism and food web carbon transfer in a wet-dry tropical river. Freshwater Biology 57:435-450.

Jackson, S., M. Finn, E. Woodward, and P. Featherstone. 2011. Indigenous socio-economic values and river flows-a summary of research results: 2008-2010. CSIRO Ecosystem Services, Darwin, Australia. (Available from: http://www.track.org .au/publications/registry/track1797)

Jardine, T. D., R. J. Hunt, S. J. Faggotter, D. Valdez, M. A. Burford, and S. E. Bunn. 2013. Carbon from periphyton supports fish biomass in waterholes of a wet-dry tropical river. River Research and Applications 29:560-573.

Jardine, T. D., N. E. Pettit, D. M. Warfe, B. J. Pusey, D. P. Ward, M. M. Douglas, P. M. Davies, and S. E. Bunn. 2012a. Consumer-resource coupling in wet-dry tropical rivers. Journal of Animal Ecology 81:310-322.

Jardine, T. D., B. J. Pusey, S. K. Hamilton, N. E. Pettit, P. M. Davies, M. M. Douglas, V. Sinnamon, I. A. Halliday, and S. E. Bunn. 2012b. Fish mediate high food web connectivity in the lower reaches of a tropical floodplain river. Oecologia (Berlin) 168:829-838.

Jones, J. B., and L. A. Smock. 1991. Transport and retention of particulate organic matter in two low-gradient headwater streams. Journal of the North American Benthological Society 10:115-126.

Kennard, M. J., B. J. Pusey, J. D. Olden, S. J. Mackay, J. L. Stein, and N. Marsh. 2010. Classification of natural flow regimes in Australia to support environmental flow management. Freshwater Biology 55:171-193.

King, A. J. 2004. Ontogenetic patterns of habitat use by fishes within the main channel of an Australian floodplain river. Journal of Fish Biology 65:1582-1603.

Knapton, A. 2009. Gulf water study: an integrated surfacegroundwater model of the Roper River Catchment, Northern Territory. Part A. Coupled surface-groundwater model. Technical Report No. 15/2009D. Water Resources Branch, Department of Natural Resources, Environment, the Arts and Sports, Darwin, Australia.

Konrad, C. P., J. D. Olden, D. A. Lytle, T. S. Melis, J. C. Schmidt, E. N. Bray, M. C. Freeman, K. B. Gido, N. P. Hemphill, M. J. Kennard, L. E. McMullen, M. C. Mims, M. Pyron, C. T. Robinson, and J. G. Williams. 2011. Large-scale flow experiments for managing river systems. BioScience 61:948-959.

Lake, P. S. 2000. Disturbance, patchiness, and diversity in streams. Journal of the North American Benthological Society 19:573592.

Lake, P. S. 2003. Ecological effects of perturbation by drought in flowing waters. Freshwater Biology 48:1161-1172.

Lamontagne, S., P. G. Cook, A. O'Grady, and D. Eamus. 2005. Groundwater use by vegetation in a tropical savanna riparian zone (Daly River, Australia). Lournal of Hydrology 310:280293.

Lehner, B., C. R. Liermann, C. Revenga, C. Vörösmarty, B. Fekete, P. Crouzet, P. Döll, M. Endejan, K. Frenken, J. Magome, C. Nilsson, J. C. Robertson, R. Rödel, N. Sindorf, and D. Wisser 2011. High-resolution mapping of the world's reservoirs and dams for sustainable river-flow management. Frontiers in Ecology and the Environment 9:494-502.

Leigh, C. 2013. Dry-season changes in macroinvertebrate assemblages of highly seasonal rivers: responses to low flow, no flow and antecedent hydrology. Hydrobiologia 703:95-112.

Leigh, C., and F. Sheldon. 2009. Hydrological connectivity drives patterns of macroinvertebrate biodiversity in floodplain rivers of the Australian wet/dry tropics. Freshwater Biology 54: 549-571.

Lewis, Jr, W. M. 2008. Physical and chemical features of tropical flowing waters. Pages 2-21 in D. Dudgeon (editor). Tropical stream ecology. Elsevier, London, UK.

Loughnane, B. 2013. 'The Coalition's 2030 vision for developing Northern Australia', Liberal Party, June 2013. The Liberal Party, Canberra, Australia. (Available from: http://www.liberal.org.au /2030-vision-developing-northern-australia)

Magoulick, D. D., and R. M. Kobza. 2003. The role of refugia for fishes during drought: a review and synthesis. Freshwater Biology 48:1186-1198.

Mastrandrea, M. D., C. B. Field, T. F. Stocker, O. Edenhofer, K. L. Ebi, D. J. Frame, H. Held, E. Kriegler, K. J. Mach, P. R. Matschoss, G.-K. Plattner, G. W. Yohe, and F. W. Zwiers. 2010. 
Guidance note for lead authors of the IPCC 5 Assessment Report on consistent treatment of uncertainties. Intergovernmental Panel on Climate Change, Jasper Ridge, USA. (Available from: http://scf.berkeley.edu/ aldous/157/Papers/ipcc_uncertainty -guidance-note.pdf)

McJannet, D., S. Marvanek, A. Kinsey-Henderson, C. Petheram, and J. Wallace. 2014. Persistence of in-stream waterholes in ephemeral rivers of tropical northern Australia and potential impacts of climate change. Marine and Freshwater Research 65:1131-1144.

McKay, S. F., and A. J. King. 2006. Potential ecological effects of water extraction in small, unregulated streams. River Research and Applications 22:1023-1037.

Miller, S. W., D. Wooster, and J. Li. 2007. Resistance and resilience of macroinvertebrates to irrigation water withdrawals. Freshwater Biology 52:2494-2510.

Morrongiello, J. R., S. J. Beatty, J. C. Bennett, D. A. Crook, D. N. E. N. Ikedife, M. J. Kennard, A. Kerezsy, M. Lintermans, D. G. McNeil, B. J. Pusey, and T. Rayner. 2011. Climate change and its implications for Australia's freshwater fish. Marine and Freshwater Research 62:1082-1098.

Nilsson C., C. A. Reidy, M. Dynesius, and C. Revenga. 2005. Fragmentation and flow regulation of the world's large river systems. Science 308:405-408.

Niu, S. Q., and D. Dudgeon. 2011. Environmental flow allocations in monsoonal Hong Kong. Freshwater Biology 56:1209-1230.

Northern Australia Land and Water Taskforce. 2009. Sustainable development of northern Australia. A report to Government from the Northern Australia Land and Water Taskforce. Department of Infrastructure, Transport, Regional Development and Local Government, Canberra, Australia. (Available from: http://www.regional.gov.au/regional/ona/nalwt.aspx)

O'Grady, A. P., D. Eamus, P. G. Cook, and S. Lamontagne. 2006. Groundwater use by riparian vegetation in the wet-dry tropics of northern Australia. Australian Journal of Botany 54: $145-154$.

Olden, J. D., C. P. Konrad, T. S. Melis, M. J. Kennard, M. C. Freeman, M. C. Mims, E. N. Bray, K. B. Gido, N. P. Hemphill, D. A. Lytle, L. E. McMullen, M. Pyron, C. T. Robinson, J. C. Schmidt, and J. G. Williams. 2014. Are large-scale flow experiments informing the science and management of freshwater ecosystems? Frontiers in Ecology and the Environment 12:176-185.

Ormerod, S. J., M. Dobson, A. G. Hildrew, and C. R. Townsend. 2010. Multiple stressors in freshwater ecosystems. Freshwater Biology 55:1-4.

Peel, M. C., B. L. Finlayson, and T. A. McMahon. 2007. Updated world map of the Köppen-Geiger climate classification. drology and Earth System Sciences 11:1633-1644.

Petheram, C., T. A. McMahon, and M. C. Peel. 2008. Flow characteristics of rivers in northern Australia: implications for development. Journal of Hydrology 357:93-111.

Petheram, C., I. Watson, and P. Stone (editors). 2013. Agricultural resource assessment for the Flinders catchment. A report to the Australian Government from the CSIRO Flinders and Gilbert Agricultural Resource Assessment, part of the North Queensland Irrigated Agriculture Strategy. CSIRO Water for a Healthy Country and Sustainable Agriculture Flagships, Australia. (Available from: http://www.csiro.au/Organisation
-Structure/Flagships/Water-for-a-Healthy-Country-Flagship /Sustainable-Yields-Projects/Flinders-and-Gilbert-Agricultural -Resource-Assessment-overview/Publications.aspx)

Pettit, N. E., T. D. Jardine, S. K. Hamilton, V. Sinnamon, D. Valdez, P. M. Davies, M. M. Douglas, and S. E. Bunn. 2012. Seasonal changes in water quality and macrophytes and the impact of cattle on tropical floodplain waterholes. Marine and Freshwater Research 63:788-800.

Poff, N. L., and J. K. H. Zimmerman. 2010. Ecological responses to altered flow regimes: a literature review to inform the science and management of environmental flows. Freshwater Biology 55:194-205.

Pusey, B., M. Kennard, and A. H. Arthington. 2004. Freshwater fishes of north-eastern Australia. CSIRO Publishing, Collingwood, Victoria, Australia.

Pusey, B., D. Warfe, S. Townsend, M. M. Douglas, D. Burrows, M. Kennard, and P. Close. 2011. Condition, impacts and threats to aquatic biodiversity. Pages 151-172 in B. J. Pusey (editor). Aquatic biodiversity in northern Australia: patterns, threats and future. Charles Darwin University Press, Darwin, Australia.

Pusey, B. J., A. H, Arthington, P. G. Close, and J. R. Bird. 2002. Larval fishes in rainforest streams: recruitment and microhabitat use. Proceedings of the Royal Society of Queensland 110:27-46.

Pusey, B. J., and M. J. Kennard. 2009. Aquatic ecosystems in northern Australia. Pages 3.1-73. in P. Stone (editor). Northern Australia Land and Water Science review. Final report to the northern Australia Land and Water Taskforce, CSIRO Publishing, Canberra, Australia. (Available from: http://www.regional .gov.au/regional/ona/nalwt.aspx)

Ramírez, J. A. 2000. Prediction and modeling of flood hydrology and hydraulics. Pages 293-346 in E. E. Wohl (editor). Inland flood hazards: human, riparian and aquatic communities. Cambridge University Press, Cambridge, UK.

Reidy-Liermann, C., C. Nilsson, J. Robertson, and R. Y. Ng. 2012. Implications of dam obstruction for global freshwater fish diversity. BioScience 62:539-548.

Rodríguez, M. A., and W. M. Lewis, Jr. 1997. Structure of fish assemblages along environmental gradients in floodplain lakes of the Orinoco River. Ecological Monographs 67:109-128.

Rolls, R. J., C. Leigh, and F. Sheldon. 2012. Mechanistic effects of low-flow hydrology on riverine ecosystems: ecological principles and consequences of alteration. Freshwater Science 31: $1163-1186$.

SKM (Sinclair Knight Merz). 2012. Impacts of groundwater extraction on streamflow in selected catchments throughout Australia. Waterlines report. National Water Commission, Canberra, Australia. (Available from: http://archive.nwc.gov.au /library/waterlines/84)

Smakhtin, V. U. 2001. Low flow hydrology: a review. Journal of Hydrology 240:147-186.

Sophocleous, S. 2002. Interactions between groundwater and surface water: the state of the science. Hydrogeology Journal 10: 52-67.

Staunton-Smith, J., J. B. Robins, D. G. Mayer, M. J. Sellin, and I. A. Halliday. 2004. Does the quantity and timing of fresh water flowing into a dry tropical estuary affect year-class strength of barramundi (Lates calcarifer)? Marine and Freshwater Research 55:787-797. 
Stewart-Koster, B., J. D. Olden, M. J. Kennard, B. J. Pusey, E. L. Boone, M. Douglas, and S. Jackson. 2011. Fish response to the temporal hierarchy of the natural flow regime in the Daly River, northern Australia. Iournal of Fish Biology 79:15251544.

Tedesco, P. A., T. Oberdorff, J.-F. Cornu, O. Beauchard, S. Brosse, H. H. Dürr, G. Grenouillet, F. Leprieur, C. Tisseuil, R. Zaiss, and B. Hugueny. 2013. A scenario for impacts of water availability loss due to climate change on riverine fish extinction rates. Journal of Applied Ecology 50:1105-1115.

Townsend, S. A. 1994. The occurrence of natural fish kills, and their causes, in the Darwin-Katherine-Jabiru region of northern Australia. Mitteilungen - Internationale Vereinigung für theoretische und angewandte Limnologie 24:197-205.

Townsend, S. A., and C. A. Edwards. 2003. A fish kill event, hypoxia and other limnological impacts associated with early wet season flow into a lake on the Mary River floodplain, tropical northern Australia. Lakes and Reservoirs: Research and Management 8:169-176.

Townsend, S. A. 2006. Hydraulic phases, persistent stratification, and phytoplankton in a tropical floodplain lake (Mary River, Northern Australia). Hydrobiologia 556:163-179.

Townsend, S. A., K. T. Boland, and T. J. Wrigley. 1992. Factors contributing to a fish kill in the Australian wet/dry tropics. Water Research 26:1039-1044.

Townsend, S. A., and A. V. Padovan. 2005. The seasonal accrual and loss of benthic algae (Spirogyra) in the Daly River, an oligotrophic river in tropical Australia. Marine and Freshwater Research 56:317-327.

Townsend, S. A., and A. V. Padovan. 2009. A model to predict the response of the benthic macroalga Spirogyra to reduced base flow in the tropical Australia. River Research and Applications 25:1193-1203.

Townsend, S. A., M. Przybylska, and M. Miloshis. 2012. Phytoplankton composition and constraints to biomass in the middle reaches of an Australian tropical river during base flow. Marine and Freshwater Research 63:48-59.

Townsend, S. A., J. H. Schult, M. M. Douglas, and S. Skinner. 2008. Does the Redfield ratio infer nutrient limitation in the macroalga Spirogyra fluviatilis? Freshwater Biology 53:509520 .
Townsend, S. A., I. T. Webster, and H. J. Schult. 2011. Metabolism in a groundwater-fed river system in the Australian wet/ dry tropics: tight coupling of photosynthesis and respiration. Journal of the North American Benthological Society 30:603620.

van Dijk, A. I. J. M., H. E. Beck, R. S. Crosbie, R. A. M. de Jeu, Y. Y. Liu, G. M. Podger, B. Timbal, and N. R. Viney. 2013. The Millennium Drought in southeast Australia (2001-2009): natural and human causes and implications for water resources, ecosystems, economy, and society. Water Resources Research 49:1040-1057.

Vörösmarty, C. J., P. B. McIntyre, M. O. Gessner, D. Dudgeon, A. Prusevich, P. Green, S. Glidden, S. E. Bunn, C. A. Sullivan, C. R. Liermann, and P. M. Davies. 2010. Global threats to human water security and river biodiversity. Nature 467:555561.

Walters, A. W., and D. M. Post. 2011. How low can you go? Impacts of a low-flow disturbance on aquatic insect communities. Ecological Applications 21:163-174.

Warfe, D. M., N. E. Pettit, P. M. Davies, B. J. Pusey, S. K. Hamilton, M. J. Kennard, S. A. Townsend, P. Bayliss, D. P. Ward, M. M. Douglas, M. A. Burford, M. Finn, S. E. Bunn and I. A. Halliday. 2011. The 'wet-dry' in the wet-dry tropics drives river ecosystem structure and processes in northern Australia. Freshwater Biology 56:2169-2195.

Webster, I. T., N. Rea, A. V. Padovan, P. Dostine, S. A. Townsend, and S. Cook. 2005. An analysis of primary production in the Daly River, a relatively unimpacted tropical river in northern Australia. Marine and Freshwater Research 56:303316.

Winemiller, K. O. 1996. Factors driving temporal and spatial variation in aquatic floodplain food webs. Pages 298-312 in G. Polis and K. Winemiller (editors). Food webs. Springer, Dordrecht, The Netherlands.

Winemiller, K. O., A. A. Agostinho, and E. P. Caramaschi. 2008. Fish ecology in tropical streams. Pages 107-146 in D. Dudgeon (editor). Tropical stream ecology. Academic Press, London, UK.

Woinarski, J., B. Mackey, H. Nix, and B. Traille. 2007. The nature of northern Australia: natural values, ecological processes and future prospects. ANU E Press, Canberra, Australia. 